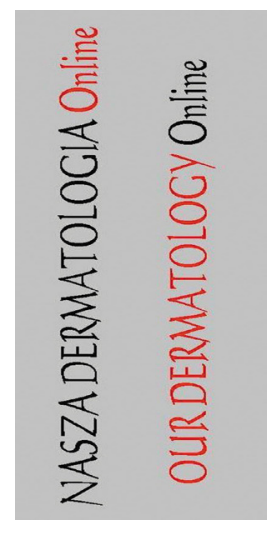

\title{
HYPERKERATOSIS OF NIPPLE AND AREOLA
} HIPERKERATOZA BRODAWKI SUTKA I OTOCZKI

\author{
Hariharasubramony Ambika, Chankramath Sujatha
}

Department of Dermatology, M.V.J. Medical College \& Research Hospital, Hoskote, Bangalore, Karnataka, India

Corresponding author: Dr Hariharasubramony Ambika ambs120269@yahoo.com

\begin{abstract}
A 26 year old pregnant female presented with verrucous lesion on nipple and areola of 10 year duration. Histopathology of lesion was consistent with benign pappiloma, which can occur with various clinical differential dignosis which cause clinical picture of hyperkeratosis of nipple and areola. It can occur as isolated entity which is idiopathic or secondary to various causes like epidermal nevus, seborrhoic keratosis, eczema, icthyosis or acanthosis nigricans. Lesion may increase in size in pregnancy and may cause worry to patient regarding nursing the babies in our case. Lesions was removed by radiofrequency cautery.
\end{abstract}

\section{Streszczenie}

26-letnia kobieta w ciąży prezentowała brodawkujące zmiany na brodawce sutka i otoczce trwające 10 lat. Histopatologia zmiany była zgodna z łagodną brodawką, która może służyć do diagnostyki różnicowej różnych obrazów klinicznych o charakterze hiperkeratozy na brodawkachiotoczkach sutka. Może onawystępowaćjakopojedynczajednostka,którajestidiopatycznalubwtórnazróżnych przyczyn, takichjak znamięnaskórkowe, rogowaceniełojotokowe, wyprysk,icthyosislubrogowacenieciemne.Zmianamożezwiększyćrozmiarwciążyimożesprawiać zakłopotanie pacjenta w zakresie opiekinad niemowlęciem, takjak w naszym przypadku. Zmiany zostały usunięte przez przeskórne przyżeganie.

Key words: hyperkeratosis; nipple; areola

Slowa klucze: rogowacenie; brodawka sutkowa; otoczka

\section{Introduction}

Hyperkeratosis of nipple and areola can occur as an idiopathic isolated condition or secondary to localised dermatosis like epidermal nevus or seborrhoeic keratosis or generalised diseases like icthyosis, eczema or acanthosis nigricans. Histopathology of lesion often help in differentiating conditions to some extent. Removal of lesion by cautery, radiofreequency or laser is curative.

\section{Case Report}

A 26 year old female primigravida of 16 weeks presented with asymptomatic hyperpigmented warty growth over right nipple of 10 years duration. There is increase in size of lesion since 1 month. Patient has not taken any treatment for this before. She was worried about recent increase in size of lesion and whether it will affect breast feeding. Examination revealed hyperpigmented verrucous plaque with pappillomatous projections over the right areola and adjacent skin (Fig. 1). Left nipple was normal. No other significant skin lesions any where else on body. With the differential diagnosis of hyperkeratosis of nipple and areola, (HKNA) epidermal naevus, seborrhoeic keratosis and verruca vulgaris, an incisional biopsy of lesion was performed. Histopathological examination showed hyperkeratosis, elongated rete ridges pappilomatosis and keratotic plugging with normal dermal architecture (Fig. 2). Histopathological feature is suggestive of benign pappiloma which can be found in most of cases of epidermal nevi seborroeic keratosis old verruca vulgaris and in nevoid HKNA. Thus clinical picture is necessary to arrive at final diagnosis. Based on clinical and histopathological features diagnosis of HKNA type 1 secondary to epidermal nevus was made. Lesion was removed with radiofrequency cautery under local anaesthesia. 


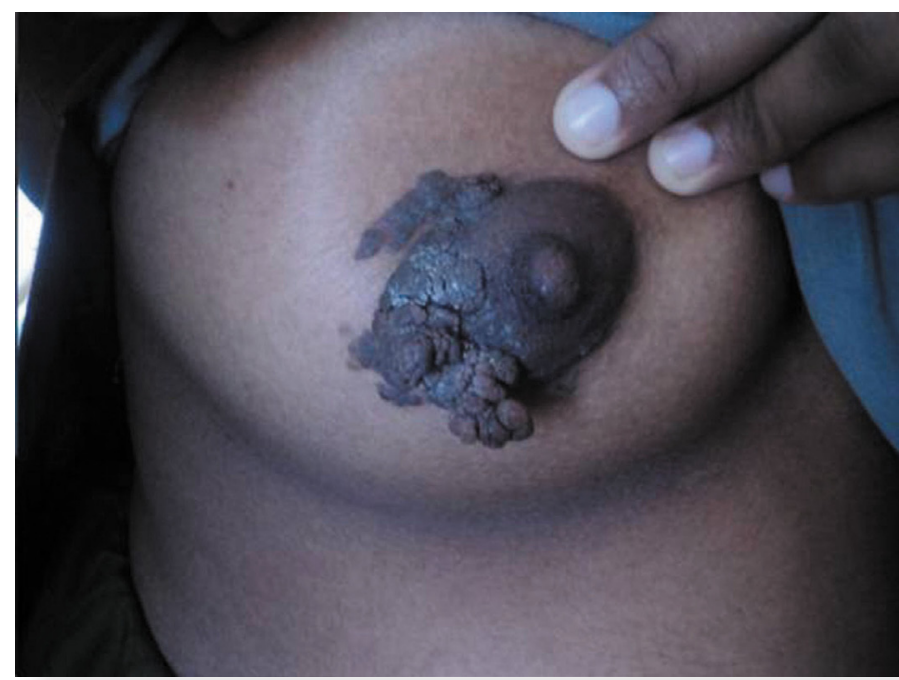

Figure 1. Hyperpigmented verrucous growth over the right areola and adjacent skin

\section{Discussion}

Hyperkeratosis of nipple and areola (HKNA) is an uncommon benign asymptomatic acquired condition of unknown pathogenesis [1]. Most of the cases are bilateral although unilateral cases can occur [2]. Clinically there is verrucous thickening of nipple and areola. There are usually no associated systemic or dermatological conditions. A change in oestrogen levels has been thought to precipitate this condition [3]. HKNA is seen more in females at puberty and pregnancy and also in males receiving hormonal therapy for prostate cancer [3]. There are doubts on whether $n$ hyperkeratosis of the nipple and areola is a distinct entity or a clinical presentation of various dermatoses. In 1938, Levy and Frankel described three distinct types of hyperkeratosis of the nipple and areola. Type I was hyperkeratosis as an extension of an epidermal nevus, type II was hyperkeratosis associated with other dermatoses (e.g., acanthosis nigricans, icthyosis, lymphoma, chronic eczema, seborrhoeic keratosis or Darier's disease), while type III was nevoid hyperkeratosis, not associated with an epidermal nevus or other dermatoses [4]. Perez-Izquierdo suggested an alternative classification of two types: idiopathic or nevoid, which may be unilateral or bilateral. Other type is secondary to local lesions like verrucous nevus or seborrheic keratosis; or associated with other diseases which include ichthyosis, Darier's disease, acanthosis nigricans chronic eczema, lymphomas, or drug related e.g., diethylstilbestrol and spironolactone [5]. Mehanna et al. suggested that the term ,nevoid' be replaced by ,idiopathic' [6]. A histopathological examination is mandatory to rule out dermatological conditions and malignancies The main cause of concern for patients of HKNA is the cosmetic appearance of the nipple and areola. and in some difficulty in feeding the baby. Various keratolitic agents like retinoic acid5 and calcipotriol [7] are found effective. Simple shave excision [8], radiofrequency [9], cryotherapy and co2 laser [10] is also effective.

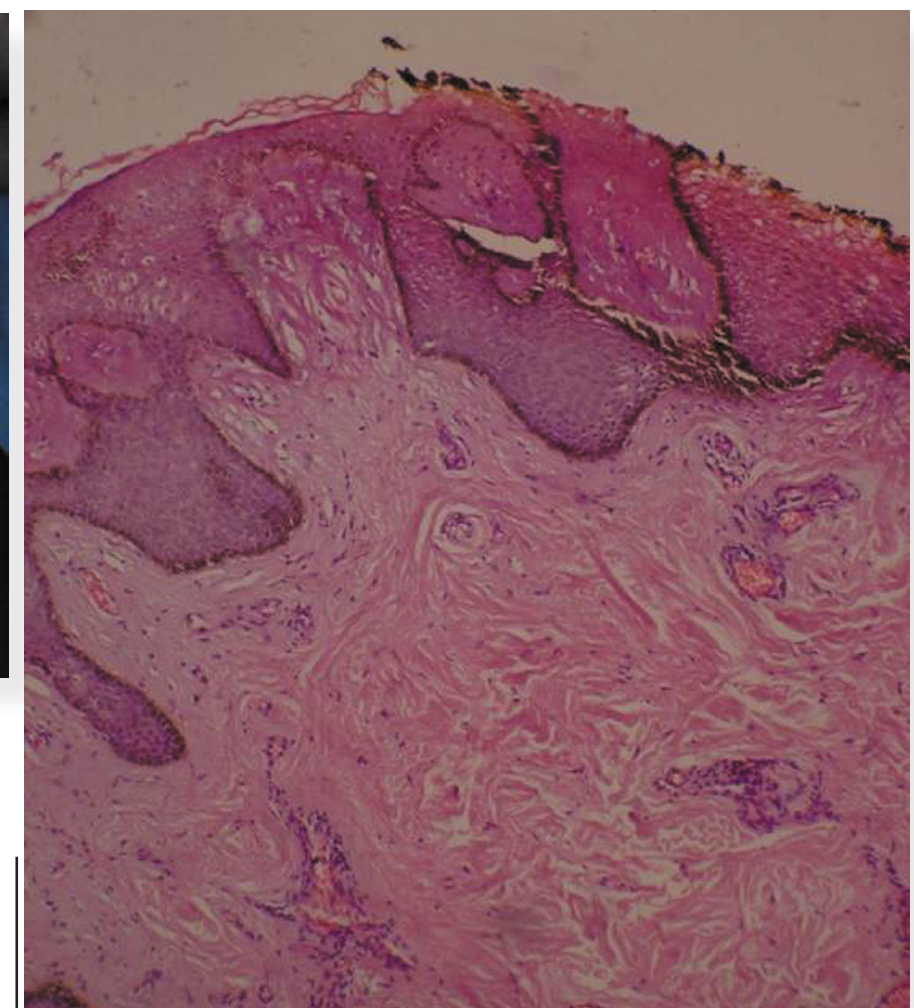

Figure 2. Biopsy showing hyperkeratosis,
elongated rete ridges, papillomatosis and keratotic plugging with normal dermal architecture. (H\&E - 40x)

\section{REFERENCES}

1. Burns DA: The Breast. In : Tony Burns, Breathnach S, Cox N, Griffith C, editors. Rook's Textbook of Dermatology, 8th ed. New York: Blackwell Science; 2009. p. 67.8-67.9.

2. Krishnan RS, Tiffany, Angel A, Roark TR, Sylvia HS: Nevoid hyperkeratosis of the nipple and/or areola: A report of two cases and a review of the literature. Int J Dermatol. 2002; 41: 775-777. 3. Mold DE, Jegasothy BV: Estrogen induced hyperkeratosis of the nipple. Cutis. 1980; 26: 95-96.

4. Levy-Franckel A: Les Hyperkeratoses de l'aerolae et du mamelon. Paris Med. 1938; 28: 63-66.

5. Perez-Izquierdo J, Vilata J, Sanchez J, Gargallo E, Millan F, Aliaga A: Retinoic treatment of nipple hyperkeratosis. Arch Dermatol. 1990; 126: 687-688.

6. Mehanna A, Malak JA, Kibbi AG: Hyperkeratosis of the nipple and areola. Arch Dermatol. 2001; 137: 1327-1328.

7. Bayramgurler D, Bilen N, Apaydin R, Ercin C: Nevoid hyperkeratosis of nipple and areola: Treatment of two patient with topical calcipotriol. J Am Acad Dermatol. 2002; 46: 131133.

8. Swan MC, Gwilym SE, Hollowood K, Venning V, Cassell O: Treatment of nevoid hyperkeratosis of the nipple and areola by shave excision. Ann Plast Surg. 2004; 53: 510-512.

9. Ozyazgan I, Kontas O, Ferahbast A:Treatment of nevoid hyperkeratosis of nipple and areola using radiofrequency surgical unit. Dermatol Surg. 2005; 31: 703-705.

10. Busse A, Peschen M, Schöpf E, Vanscheidt W: Treatment of hyperkeratosis areolae mammae naeviformis with carbon dioxide laser. J Am Acad Dermatol. 1999; 41: 274-276.

Copyright by Hariharasubramony Ambika et al. This is an open access article distributed under the terms of the Creative Commons Attribution License, which permits unrestricted use, distribution, and reproduction in any medium, provided the original author and source are credited. 